\title{
PROFITABILITAS PADA BANK UMUM SYARIAH DENGAN DENGAN SOLVABILITAS SEBAGAI PEMODERASI
}

\author{
Ika Noviyanti ${ }^{1}$, Mohammad Rofiuddin ${ }^{2 *}$ \\ ${ }^{1,2}$ Prodi Perbankan Syariah, Fakultas Ekonomi dan Bisnis Islam, IAIN Salatiga \\ *Corresponding Author email: mohammad.rofiuddin@iainsalatiga.ac.id, \\ ikanoviyanti.psfebi@gmail.com

\begin{tabular}{l|l|l|} 
Masuk: Juli 2021 & Penerimaan: Agustus 2021 & Publikasi: September 2021 \\
\hline
\end{tabular}

\begin{abstract}
ABSTRAK
Penelitian ini bertujuan untuk menganalisis pengaruh DPK, FDR dan PSR terhadap Profitabilitas dengan tingkat solvabilitas sebagai pemoderasi pada Bank Umum Syariah. Jenis penelitian ini adalah penelitian kuantitatif dengan data sekunder berbentuk panel. Sampel yang digunakan dalam penelitian ini sebanyak 10 bank dengan teknik pengambilan sampel menggunakan purposive sampling. Teknik analisis yang digunakan adalah analisis regresi linier berganda. Hasil pada penelitian ini menunjukkan bahwa variabel DPK, FDR dan Tingkat Solvabilitas berpengaruh negatif terhadap Profitabilitas. Sedangkan Profit Sharing berpengaruh positif terhadap Profitabilitas. Adapun Tingkat Solvabilitas mampu memoderasi pengaruh DPK, FDR dan Profit Sharing terhadap Profitabilitas.
\end{abstract}

Kata Kunci : DPK, FDR, PSR, Profitabilitas, dan Tingkat Solvabilitas.

\begin{abstract}
ABSTRACK
This research aims to analyze the effect of Depositor Funds, Financing to Deposit Ratio and Profit Sharing on profitability with the level of solvency as moderating in Islamic Commercial Banks. This type of research is quantitative research with secondary data in the form of panels. The sample used in this study were 10 banks with a sampling technique using purposive sampling. The analysis technique used is multiple linear regression analysis. The results of this study indicate that the variables of Depositor Funds, Financing to Deposit Ratio and Solvency Level have a negative effect on Profitability. While Profit Sharing has a positive effect on profitability. Solvency level is able to moderate the influence of Depositor Funds, Financing to Deposit Ratioand Profit Sharing on Profitability.

Keyword: Depositor Funds, Financing To Deposit Ratio, Profit Sharing, Profitability and Solvency Level
\end{abstract}

\section{A. PENDAHULUAN}

Bank syariah memainkan peran penting dalam perekonomian dan aktivitas perdagangan suatu negara. Industri perbankan tidak dapat dipisahkan dari kegiatan pembangunan perekonomian, karena pertumbuhan ekonomi yang stabil yaitu dengan memegang peranan industri perbankan. Dalam kegiatan usahanya, bank didasarkan pada Prinsip Syariah. Bank, sebagai lembaga keuangan, berfungsi sebagai perantara keuangan baik dalam situasi keuangan berlebih maupun tidak 
mencukupi. Ketika bank gagal menjalankan fungsinya secara normal, hal itu akan mengakibatkan pertumbuhan ekonomi dan menghambat pembangunan nasional.

Perbankan syariah mencakup seluruh aspek yang meliputi bank syariah dan unit usaha sariah, termasuk kelembagaan, proses operasional, serta proses dan tata cara berbisnis. Virus Covid-19 menyebabkan penurunan pendapatan bagi sektor Perbankan. Tetapi jika dibandingkan dengan industri perbankan lebih tinggi nilainya. Profitabilitas bank tahun ini dengan tahun sebelumnya diperkirakan tidak stabil. Karena situasi keuangan global, tingkat pembiayaan Bank Umum Syariah dan beban lukuiditas mungkin akan terhambat (BUS). Menurut Otoritas Jasa Keuangan, laba bersih komulatif BUS dan UUS adalah Rp. 6,67 triliun pada November 2019, meningkat 26,5\% tahun ke tahun. Perkembangan pada tahun 2017 dan 2018 ialah pencapaian terendah yang mampu berkembang sekitar 50\%. Secara keseluruhan perkembangan aset dan pembiayaan menjadi lambat dan berdampak negatif pada pendapatan margin perbankan syariah.

Indikator yang tepat guna menilai baik atau buruknya kineja bank, dapat ditinjau berdasarkan perolehan labanya, karena bank sangat dubutuhkan dalam menjaga kinerjanya dengan baik. Bank Indonesia sebagai pembimbing serta pengawas pebankan memilih profitabilitas yang dinilai memakai ROA, hal ini dikarenakan ROA memfokuskan pada kemampuan perusahaan dalam mendatangkan laba yang dipakai guna melaksanakan operasional perusahaan dengan memanfatkan asset produktif yang dimilikinya. Jadi apabila ROA memilki nilai yang tinggi maka laba bank tersebut semakin tinggi pula, sehingga akan berdampak pada pemegang saham dengan peningkatan profitabilitasnya (Husnan, 1998). Mengacu pada tingkat perubahan ROA pada Bank Umum Syariah, didapatkan informasi dapat dilihat pada Gambar 1. 


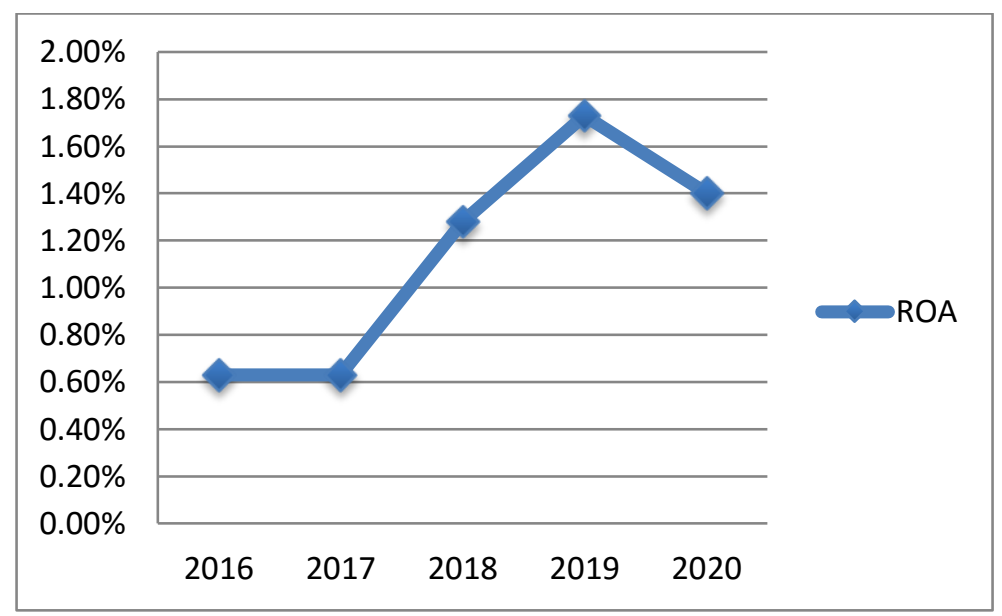

Sumber : OJK, data diolah 2021

Gambar 1. ROA pada Bank Umum Syariah

Berdasarkan Gambar 1, menunjukan bahwa tingkat perubahan profitabilitas dari tahun ke tahun mengalami perubahan. Tahun 2016 dan tahun 2017 memiliki porsi yang sama sebesar 0,63\%. Lebih tinggi dari tahun 2018 yaitu sebesar 1,28\% dan tahun 2019 mencapai 1,73\%. Namun pada tahun 2020 ROA mengalami penurunan menjadi $1,40 \%$. Hal ini dapat dilihat bahwa semakin banyak bank diminati, maka semakin besar total aset serta keuntungan jumlah profitabilitas akan meningkat. Dengan demikian, bank syariah memiliki dampak positif dalam meningkatkan kinerjanya.

Salah satu faktor yang mendorong tingkat Profitabilitas meningkat yaitu DPK. DPK selama ini menjadi cara paling khas bagi bank syariah untuk menghimpun dana dari masyarakat umum. Pentingnya DPK ini karena pendapatan akan diberikan dalam bentuk pembiayaan/kredit yang berupa giro, tabungan dan deposito (Dendawijaya, 2009). Apabila DPK dalam kondisi normal, hingga pemberian kredit maka akan terus menjadi besar. Bila dana yang dikumpulkan dari masyarakat besar, keputusan buat memusatkan kredit juga lebih besar. Dengan demikian, jika dana yang dikumpulkan semakin banyak maka profitabilitas juga akan meningkat. Sumber dana bank yang paling terpercaya adalah DPK yang dikumpulkan dari keseluruhan populasi (80\%-90\% dari seluruh dana yang dikelola oleh bank). Bila modal yang dimilki bank terbatas hingga aktivitas usaha bank berjalan dengan mudah dengan kondisi nyaman sebab mempunyai cadangan modal yang lumayan. 
Studi empiris terkait DPK terhadap profitabilitas. Berdasarkan hasil penelitian Afrizal (2017), Husaeni (2017), dan Asri dan Suarjaya (2018) dengan hasil penelitiannya yaitu positif terhadap profitabilitas. Sedangkan Sihombing dan Yahya (2016), Mahmudah dan Harjanti (2016) dengan penelitiannya masingmasing mempunyai hasil yang berbeda, dari penelitian mereka diketahui bahwa DPK memiliki pengaruh negatif terhadap profitabilitas.

Profitabilitasjuga dipengaruhi oleh FDR atau tingkat likuiditas. Penentuan tinggi rendahnya tingkat FDR diperoleh dari pembiayaan yang diberikan untuk nasabah yang dibandingkan dengan jumlah dana terhimpun seperti pada produk giro, deposito, maupun tabungan. Kemudian komponen-komponen tersebut nantinya akan didapat jumlah pendistribuan dari bagi hasil pada setiap jenis dana yang dihimpun oleh bank. Dengan demikian, agar kondisi likuiditas bank tetap terjaga maka bank harus bisa mengolah dan mengoptimalkan dana dengan sebaikbaiknya. Apabila bank memiliki FDR tinggi, tentu bank berusaha dalam meningkatkan dana yang diperolehnya sehingga dapat meningkatkan profitabilitas (Mokoagow, S. W., 2015).

Berdasarkan isu pengaruh FDR terhadap profitabilitas, dimana Almunawwaroh dan Marliana (2018), Juniarto Koko Mochamad (2018) dan Simatupang dan Franzlay (2016) pada penelitiannya masing-masing menyatakan positif. Sedangkan Munir (2018) dan Mahmudah dan Harjanti (2016) memiliki hasil penelitian yaitu FDR berpengaruh negatif terhadap profitabilitas.

Faktor lainnya adalah Profit Sharing (bagi hasil) merupakan indikator penting dalam alokasi dana bank. Hal ini dapat tergambar dari besar akumulasi pembiayaan yang akan disalurkan oleh sebuah lembaga keuangan kepada nasabahnya. Sudarsono (2008) menegaskan bahwa produk pembiayaan bank syariah, termasuk pembiayaan musyarakah dan mudharabah, berpusat pada prinsip bagi hasil. Bank syariah nantinya akan mendapatkan pendapatan bagi hasil dari pembiayaan bank syariah yang juga disalurkan melalui sistem bagi hasil. Pembiayaan perbankan syariah akan lebih tinggi jika bagi hasil yang tinggi di perbankan syariah.

Penelitian terdahulu terkait dengan bagi hasil terhadap profitabilitas. Menurut Medyawati dan Yunanto (2018) dan Risalah et al. (2018) pada penelitian 
masing-masing dengan hasil positif. Kemudian Angraini (2018) dan Gunawan et al.(2019) pada penelitiannya dengan hasil negatif terhadap profitabilitas.

Rasio Solvabilitas (leverage) diprediksi dengan rasio hutang terhadap ekuitas (DER). Jika perusahaan akan dibubarkan, perlu diketahui bagaimana kemampuan untuk melunasi hutang jangka pendek dan panjang dengan melihat rasio solvabilitas (Kasmir, 2010). Rasio DER menggambarkan bagaimana kemampuan modal yang dimiliki untuk menutupi hutang. Tingginya ketergantungan perusahaan dengan pihak eksternal merupakan cerminan dari besarnya rasio DER. Hal ini akan membuat perusahaan memiliki resiko dalam memenuhi hutangnya, yakni membayar bunga dan pokoknya.

Penelitian terdahulu terkait dengan solvabilitas terhadap profitabilitas. Menurut Minrai (2019) dan juga pendapatnya Pakpahan (2016) bahwa tingkat solvabilitas memilki pengaruh positif. Namun, hasil riset ini bertentangan dengan hasil riset Rizki (2019) yang mengatakan bahwa tingkat solvabilitas terhadap profitabilitas berpengaruh negatif.

Dalam riset ini, terdapat perbedaan dengan penelitian sebelumnya diantaranya yaitu adanya variabel moderating yaitu Tingkat Solvabilitas. Dengan adanya Tingkat Solvabilitas dengan menggunakan uji MRA tentu sangat mempengaruhi variabel dependen dengan variabel independen yang dapat memperkuat hubungan tersebut. Dengan BUS yang terdaftar di OJK dalam jangka waktu 5 tahun yaitu 2016-2020.

Berdasarkan pemaparan latar belakang mengenai apa yang telah diteliti oleh para pendahulu, masih terdapat beberapa perbedaan yang terpecah yang menjadi peluang untuk dilakukan penelitian kembali, maka akan dilakukan suatu penelitian mengenai pengaruh DPK, FDR serta PSR terhadap profitabilitas dengan Tingkat Solvabilitas sebagai variabel Moderating.

\section{B. TELAAH TEORITIS}

\section{Signaling Theory (Teori Sinyal)}

MenurutMarlinah (2014) tentang teori sinyal, jika di sebuah perusahaan berada di fase yang lebih tinggi maka manajer memberikan pemahaman kepada investor melalui laporan keuangan. Manfaat dari teori sinyal yaitu ketika dalam 
dorongan para manajer berusaha untuk mengharapkan profit sebuah dari perusahaan yang lebih tinggi melalui investasi yang percaya pada perusahaan dan nilai saham akan lebih tinggi dan juga pemegang saham akan memperoleh keuntungan.

Teori sinyal mengatakan kepada pengguna laporan keuangan bahwa ada asimetri informasi antara perusahaan dan investor. Pemahaman yang disampaikan dapat berupa informasi guna mencapai harapan pemilik. Sinyal tersebut dapat berupa iklan atau informasi yang menunjukkan bagaimana perusahaan lebih unggul dari yang lain. Dengan catatan bahwa perusahaan memiliki informasi yang lebih luas dari pada informasi dari pihak eksternal. Dalam memberikan asimetri informasi dengan meminimalisir informasi salah satunya memberikan laporan keuangan yang dapat dipercaya oleh perusahaan.

\section{Dana Pihak Ketiga dan Profitabilitas}

Dana simpanan yang berasal dari simpanan masyarakat dikenal dengan istilah dana pihak ketiga, untuk pengambilan dananya menggunakan media tertentu dan dapat dilakukan kapan saja. Keuangan publik selanjutnya dikelola semaksimal mungkin oleh sektor perbankan, yang membentuk kegiatan operasional bank syariah. DPK merupakan sumber pendanaan terbesar bagi kegiatan bank syariah, nilainya pada kisaran 80\% - 90\%. Semakin besar DPK maka semakin banyak pula dana bank yang akan dikembalikan kepada masyarakat dalam bentuk kredit. Akibatnya, jumlah pendapatan yang diperoleh dari bagi hasil akan meningkat.

\section{Financing to Deposit Ratio (FDR) dan Profitabilitas}

FDR adalah rasio yang digunakan untuk mengukur likuiditas suatu bank dadalam memenuhi kewajibannya, serta seberapa mampu bank memenuhi pembiayaan yang diajukan nasabah. Menurut Harun (2016) tingkatan normal FDR 85-100\% dan harus terus dijaga pada tingkatan tersebut, karena likuiditas bank tercermin dari tingkat FDR. Jika FDR jauh lebih rendah dari batas normal, artinya bank menyimpan terlalu banyak uang tunai yang akan meningkatkan biaya peeliharaan uang tunai. Apabila batas normal FDR terlampau lebih tinggi, maka perbankan akan menanggung biaya untuk alokasi pembiayaan ke masyarakat lebih tinggi juga. Biaya tersebut akan mengurangi profit bank, karena biaya tersebut termasuk beban operasional bank. 


\section{4. $\quad$ Profit sharingdan Profitabilitas}

Profit sharing secara istilah yaitu pembagian hasil usaha berdasarkan total pendapatan dikurangi total biaya yang dikeluarkan Andrianto and Firmansyah (2019). Profit sharing merupakan pembagian laba dan kerugian yang berlaku untuk hubungan kerja antara bank dan nasabah selama perjanjian kerjasama (Hassoune, 2005). Wujud dari bagi hasil bisa berupa uang tahunan sebagai bonus tunai dengan berdasar pada periode sebelumnya dalam perolehan laba, bisa berwujud pembayaran dari mingguan bahkan kurun waktu antar bulan. Berlakunya bagi hasil pada bank syariah dari pendapatan pada produk berbasis penyertaan baik menyeluruh atau dari penyertaan sebagian pada kerjasama (Yudiana, 2014).

\section{Solvabilitas, Dana Pihak Ketiga, Financing to Deposit Ratio (FDR),}

\section{Profit sharing Terhadap Profitabilitas}

Menurut Ariani dan Bawono (2018), solvabilitas ditentukan dengan membandingkan total aset dengan total hutang. Patokan ini mengharuskan korporasi dapat memenuhi seluruh kewajibannya, baik kewajiban jangka pendek maupun jangka panjang. Ketika sebuah perusahaan dibubarkan, solvabilitas biasanya digunakan untuk membiayai semua hutang jangka pendek dan panjang.

\section{METODE PENELITIAN}

Data yang digunakan dalam riset ini adalah data sekunder. Jenis penelitian yang dilakukan ini merupakan penelitian kuantitatif. Populasi diperoleh sejumlah 14 bank dan sampel sebanyak 10 bank dengan teknik pengambilan sampel menggunakan purposive sampling. Diantaranya Bank Victoria Syariah, Bank Mega Syariah, Bank Muamalat Syariah, Bank BCA Syariah, Bank Panin Syariah, Bank Syariah Mandiri, Bank Jabar Syariah, Bank BRI Syariah, Bank Bukopin Syariah, Bank BNI Syariah.Teknik analisis yang digunakan adalah regresi linier berganda dengan menggunakan metode Moderated Regression Analysis.

$$
\begin{gathered}
\text { Prof }=\beta 0+\beta 1 D P K+\beta 2 F D R+\beta 3 P S R+\beta 3 S O L V+\beta 4 D P K * S O L V \\
+\beta 5 F D R * S O L V+\beta 6 P S R * S O L V+\varepsilon
\end{gathered}
$$

Keterangan :

Prof $=$ Profitabilitas

$\beta 0=$ Konstanta

DPK $=$ Dana Pihak Ketiga

FDR = Financing To Deposit Ratio 


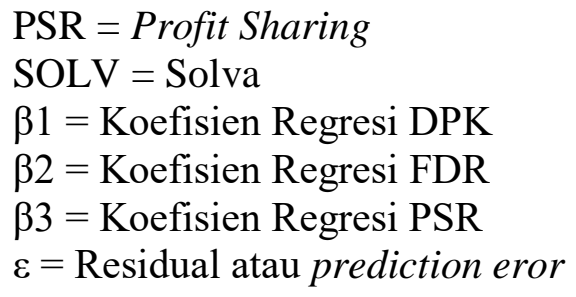

Selanjutnya dari model tersebut dilanjutkan dengan pengujian asumsi klasik (uji normalitas, multikolinieritas, heteroskedastisitas dan autokorelasi). Uji kebaikan model (uji koefisien determinasi dan uji validitas pengaruh (uji T).

\section{HASIL DAN PEMBAHASAN}

\section{Deskripsi Data}

Riset ini menggunakan BUS yang tercatat di OJK kurun waktu 2016-2020 selaku objek bagi riset. Dengan populasi sebanyak 14 Bank Umum Syariah. Laporan keuangan tahunan pada masing-masing bank menjadi data yang digunakan pada riset ini dengan syarat memenuhi kriteria penetuan sampel. Terdapat 10 BUS yang memenuhi kriteria untuk sampel dengan total hasil pemilihan sampel diperoleh sebanyak 50 data penelitian. Uji ini bertujuan untuk melihat nilai mean, maksimum dan minimum dari Dana Pihak Keriga, Financing to Deposit Ratio, Profit Sharing dan Tingkat Solvabilitas.

\section{Uji ModeratedRegression Analisys (MRA)}

Moderated Regression Analysis dalam penelitian ini menggunakan pendekatan model regresi data panel, adapun hasil regresinya dipilihlah model terbaik yaitu Fixed Effect Model (FEM).

Tabel 1.Persamaan MRA dengan pendekatan FEM

\begin{tabular}{crrrr}
\hline Variable & Coefficient & Std, Error & t-Statistic & \multicolumn{1}{c}{ Prob, } \\
\hline C & 6,744855 & 1,294477 & 5,210488 & $0,0000^{*}$ \\
DPK & $-5,93 E-06$ & $1,90 \mathrm{E}-05$ & $-0,312334$ & 0,7568 \\
FDR & $-0,067418$ & 0,014503 & $-4,648624$ & $0,0001^{*}$ \\
PSR & 0,163613 & 0,083279 & 1,964649 & $0,0579 * * *$ \\
SOLVA & $-2,439005$ & 0,489390 & $-4,983766$ & $0,0000^{*}$ \\
DPK*SOLVA & $1,01 \mathrm{E}-05$ & $4,48 \mathrm{E}-06$ & 2,261125 & $0,0305^{* *}$ \\
FDR*SOLVA & 0,021757 & 0,005619 & 3,872103 & $0,0005^{*}$ \\
PSR*SOLVA & 0,129494 & 0,061166 & 2,117089 & $0,0419^{* *}$ \\
\hline R-squared & 0,987098 Durbin-Watson stat & 1,999248 \\
Adjusted R-squared & 0,980842 & & & \\
F-statistic & 157,7924 & & & \\
Prob(F-statistic) & 0,000000 & & & \\
\hline
\end{tabular}


Keterangan: *signifikan pada level 0,01; **signifikan pada level 0,05; *** signifikan pada level 0,10

Sumber: Data sekunder diolah,2021

Secara matematis hasil regresi pada Tabel 1 dapat dirumuskan sebagai berikut:

$$
\begin{aligned}
& \text { Prof }=6,745-5,93 E-06(D P K)-0,067(F D R)+0,163(P S R)-2,439(S O L V A) \\
&+1,01 E-5(D P K * S O L V A)+0,022(F D R * S O L V A)+0,129(P S R \\
&* \text { SOLVA })
\end{aligned}
$$

\section{Uji Normalitas}

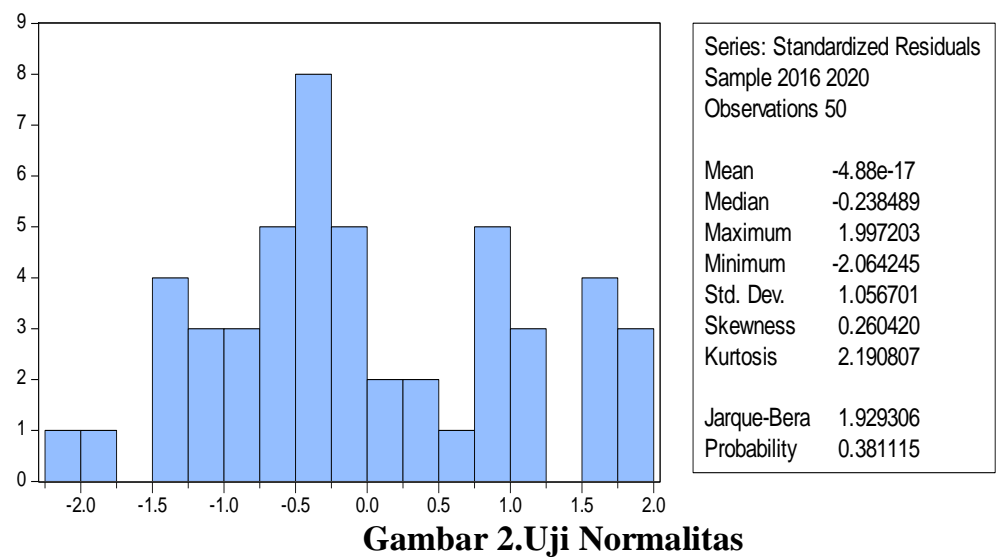

Gambar 2 menunjukan bahwa nilai Jarque Bera sebesar 1,929306 serta Probability sebesar 0,381115>0,05, maka dapat dikatakan data pada penelitian ini berdistribusi normal.

\section{Uji Multikoliniearitas}

Dari Tabel 2, dapat dilihat bahwa tidak ada hubungan antara variabel independen dengan nilai $\mathrm{R}^{2}$ pada nilai regresi utama. Diambil kesimpulan bahwa data pada riset ini tidak ada masalah multikolinieritas.

Tabel 2. Uji Multikolinieritas dengan R auxiliary

\begin{tabular}{clc}
\hline No & \multicolumn{1}{c}{ R-Squared } & R2 Utama $=0,987098$ \\
\hline 1 & DPK $=0,965473^{*}$ & Lebih Kecil \\
2 & FDR $=0,695234^{*}$ & Lebih Kecil \\
3 & PSR $=0,877661^{*}$ & Lebih Kecil \\
4 & SOLVA $=0,883333^{*}$ & Lebih Kecil \\
\hline
\end{tabular}

Keterangan: *tidak terjadi multikolinearitas 


\section{Uji Heteroskedastisitas}

Tabel 3. Uji Glejser

\begin{tabular}{crrrr}
\hline Variable & Coefficient & Std,Error & t-Statistic & Prob, \\
\hline C & $-2,072199$ & 1,466011 & $-1,413495$ & 0,1669 \\
DPK & $-1,85 \mathrm{E}-06$ & $2,46 \mathrm{E}-05$ & $-0,075247$ & 0,9405 \\
FDR & 0,032154 & 0,016050 & 2,003290 & 0,0534 \\
PSR & $-0,008342$ & 0,105178 & $-0,079309$ & 0,9373 \\
SOLVA & 1,045909 & 0,525983 & 1,988485 & 0,0551 \\
DPK*SOLVA & $-6,89 \mathrm{E}-07$ & $5,90 \mathrm{E}-06$ & $-0,116915$ & 0,9076 \\
FDR*SOLVA & $-0,011990$ & 0,006003 & $-1,997536$ & 0,0541 \\
PSR*SOLVA & $-0,004691$ & 0,090440 & $-0,051864$ & 0,9589 \\
\hline
\end{tabular}

Sumber: Data sekunder diolah,2021

Berdasarkan Tabel 3 dapat dilihat bahwa probability antar variabel $>0.05$, diambil kesimpulan bahwa data pada riset ini terbebas dari gejala heteroskedastisitas.

\section{Uji Autokorelasi}

Tabel 4. Uji Autokorelasi

\begin{tabular}{lll}
\hline & Weighted Statistics & \\
\hline R-squared & 0,987098 Durbin-Watson stat & 1,999248 \\
Adjusted R-squared & 0,980842 & \\
F-statistic & 157,7924 \\
Prob(F-statistic) & 0,000000
\end{tabular}

Sumber: Data sekunder diolah,2021

Tabel 5. Durbin Watson

\begin{tabular}{ccccc}
\hline DL & DU & & 4-DU & 4-DL \\
\hline 1,2461 & 1,8750 & 1,999248 & 2,125 & 2,7539 \\
\hline
\end{tabular}

Berdasarkan Tabel 5 diperoleh nilai DW 1,999248, dapat diartikan jika model regresi terbebas dari autokorelasi. Nilai DW tersebut berada diantara DU dan 4-DU. Adapun nilai DU di angka 1,8750 dan nilai 4-DU adalah 2,125. Maka DU < DW $<4$-DU.

\section{Uji Validitas Pengaruh}

a. DPK Terhadap Profitabilitas

Diketahui uji pada Tabel 1 variabel DPK menunjukkan nilai t hitung 0,312334 dan nilai prob0,7568 yang artinya lebih besar dari nilai alpha 0,05. 
Maka variabel DPK tidak berpengaruh terhadap profitabilitas. Merujuk pada hasil ini maka $\mathrm{H} 1$ dalam penelitian ini disimpulkan bahwa H1 ditolak.

b. FDR Terhadap Profitabilitas

Diketahui uji pada Tabel 1 variabel FDR menunjukkan nilai t hitung 4,648624dan nilai prob 0,0001 yang artinya lebih kecil dari nilai alpha 0,05. Maka variabel FDR tidak berpengaruh terhadap profitabilitas. Merujuk pada hasil ini maka $\mathrm{H} 2$ dalam penelitian ini disimpulkan bahwa $\mathrm{H} 2$ ditolak.

c. PSR Terhadap Profitabilitas

Diketahui uji pada Tabel 1 variabel PSR menunjukkan nilai t hitung 1,964649 dan nilai prob 0,0579 yang artinya lebih besar dari nilai alpha 0,05 (tidak signifikan), namun begitu pada level signifikansi 0,1 maka nilai prob0,0579 $<0,1$ (signifikan). Sehingga variabel Profit Sharing berpengaruh positif terhadap profitabilitas. Merujuk pada hasil ini maka H3 dalam penelitian ini disimpulkan bahwa $\mathrm{H} 3$ diterima.

d. Tingkat Solvabilitas Terhadap Profitabilitas

Diketahui uji pada Tabel 1 variabel SOLVA menunjukkan nilai t hitung 4,983766 dan nilai prob 0,0000 yang artinya lebih kecil dari nilai alpha 0,05.

Sehingga variabel solvabilitas tidak berpengaruh terhadap profitabilitas.

Merujuk pada hasil ini maka $\mathrm{H} 4$ dalam penelitian ini disimpulkan bahwa H4 ditolak.

e. Tingkat Solvabilitas dalam Memoderasi DPK terhadap Profitabilitas

Diketahui uji pada Tabel 1 variabel DPK*SOLVA menunjukkan nilai $\mathrm{t}$ hitung 2,261125 dan nilai prob 0,0305 yang artinya lebih kecil dari nilai alpha 0,05. Sehingga tingkat solvabilitas dapat memoderasi pengaruh DPK terhadap profitabilitas. Merujuk pada hasil ini maka H5 dalam penelitian ini disimpulkan bahwa H5 diterima.

f. Tingkat Solvabilitas dalam Memoderasi FDR terhadap Profitabilitas

Diketahui uji pada Tabel 1 variabel FDR*SOLVA menunjukkan nilai $\mathrm{t}$ hitung 3,872103 dan nilai prob 0,0005 yang artinya lebih kecil dari nilai alpha 0,05. Sehingga tingkat solvabilitas dapat memoderasi pengaruh FDR terhadap profitabilitas. Merujuk pada hasil ini maka H6 dalam penelitian ini disimpulkan bahwa H6 diterima. 
g. Tingkat Solvabilitas dalam Memoderasi Profit Sharing terhadap Profitabilitas

Diketahui uji pada Tabel 1 variabel PSR*SOLVA menunjukkan nilai $\mathrm{t}$ hitung 2,117089 dan nilai prob 0,0419 yang artinya lebih kecil dari nilai alpha 0,05. Sehingga tingkat solvabilitas dapat memoderasi pengaruh PSR terhadap profitabilitas. Merujuk pada hasil ini maka $\mathrm{H} 7$ dalam penelitian ini disimpulkan bahwa $\mathrm{H} 7$ diterima.

\section{Uji R2 (Koefisien Determinasi)}

Mengacu pada hasil uji regresi Tabel 1, didapatkan bahwa model regresi antara variabel independen dan dependen memilki nilai koefisien determinasi pada $R$-squared 0,987098, artinya variabel DPK, FDR, dan PSR mampu menjelaskan variabel profitabilitas sebesar 98,7098\%.

\section{E. PEMBAHASAN}

\section{Pengaruh Pengaruh DPK terhadap Profitabilitas}

Berdasarkan hasil uji t, menunjukan bahwasanya variabel DPK tidak berpengaruh terhadap profitabilitas. Artinya, semakin meningkatnya DPK maupun turunnya DPK tidak mempengaruhi terhadap profitabilitas. Kondisi ini bisa jadi karena tidak maksimalnya DPK digunakan atau disalurkan dalam bentuk pembiayaan.

Penelitian ini sejalan dengan Mahmudah dan Harjanti (2016) diketahui bahwa DPK memilki pengaruh negatif. Begitu juga pendapatnya Sihombing dan Yahya (2016) bahwa DPK memilki pengaruh negatif. Hal ini dikarenakan pembiayaan yang disalurkan ini tidak sebanding dengan banyaknya dana yang dimiliki oleh bank. Dan juga kurang maksimalnya dalam penyaluran dana sehingga dapat menyebabkan meningkatnya pembiayaan bermasalah dan pada akhirnya dapat menurunkan tingkat profitabilitas.

\section{Pengaruh FDR terhadap Profitabilitas}

Berdasarkan hasil uji t, FDR memiliki pengaruh negatif terhadap profitabilitas. Artinya, semakin besar FDR, semakin kecil likuiditas bank tersebut. Ini bisa jadi karena FDR rata-rata bank-bank besar sangat rendah sehingga tidak berpengaruh pada profitabilitas. Penelitian ini sejalan dengan pendapat Mahmudah dan Harjanti (2016) diketahui bahwa FDR memilki pengaruh negatif. Begitu juga 
pendapatnya Munir (2018) bahwa FDR memilki pengaruh negatif. Hal ini dikarenakan pembiayaan bank belum berfungsi dengan lancar, sehingga terjadi peningkatan pembiayaan dan kurang lancarnya pembiayaan bank secara keseluruhan.

\section{Pengaruh Profit Sharing terhadap Profitabilitas}

Berdasarkan hasil uji t, bahwa variabel profit sharing memliki pengaruh positif terhadap profitabilitas, sehingga profit sharing dapat mempengaruhi profitabilitas. Artinya jika bank menawarkan bagi hasil yang tinggi kepada konsumen, maka nasabah akan menaikkan jumlah uang yang terkumpul di bank. Akibatnya, profitabilitas bank meningkat.

Hasil penelitian ini didukung dengan penelitian Medyawati dan Yunanto (2018)bahwasanya profit sharing memilki pengaruh positif. Begitu juga pendapatnyaKurniawansyah (2016) dan Risalah et al. (2018)bahwa profit sharing memilki pengaruh positif. Sesuai dengan hasil riset ini besar kecilnya profit sharing yang diperoleh bank tidak dapat meningkatkan profitabilitas. Sehingga bank harus lebih memaksimalkan dalam melakukan pembiayaan berprinsip bagi hasil dan melakukan analisis yang lebih baik agar tidak terjadi pembiayaan bermasalah, sehingga pendapatan bagi hasil yang diperoleh dapat maksimal dan dapat berkontribusi meningkatkan profitabilitas.

\section{Pengaruh Tingkat Solvabilitas terhadap Profitabilitas}

Berdasarkan hasil uji t, tingkat solvabilitas memiliki pengaruh negatif terhadap profitabilitas, sehingga tingkat solvabilitas tidak dapat mempengaruhi profitabilitas. Artinya, tingkat solvabilitas yang rendah menunjukan bahwa modal dan aset lancar tidak mencukupi untuk membiayai semua hutang jangka pendek dan jangka panjang. Jika rasio solvabilitas rendah, perusahaan akan berisiko kehilangan uang, dan biaya untuk membayar utang akan meningkat. Akibatnya, profitabilitas menderita. Menurut Rizki (2019), semakin tinggi debt ratio yang diterapkan perusahaan, maka semakin banyak pula pembayaran utang dan bunga yang harus ditanggung perusahaan sehingga mengurangi keuntungan perusahaan.

\section{Tingkat Solvabilitas dalam Memoderasi DPK terhadap Profitabilitas}

Sesuai dengan hasil riset ini, dapat disimpulkan bahwa tingkat solvabilitas memperkuat pengaruh DPK terhadap profitabilitas. Artinya, jika pihak bank dapat 
mengumpulkan DPK lebih banyak, maka profitabilitas juga akan semakin tinggi dan bank akan mampu membayar kewajiban-kewajibannya. Menurut Minrai (2019) dan Pakpahan (2016) menunjukan hasil bahwa tingkat solvabilitas memilki pengaruh positif. Dapat diartikan jika dana yang dikumpulkan semakin banyak maka profitabilitas juga akan semakin meningkat. Namun, hasil ini bertentangan dengan hasil riset Rizki (2019) yang mengatakan bahwa tingkat solvabilitas terhadap profitabilitas berpengaruh negatif.

\section{Tingkat Solvabilitas dalam Memoderasi FDR terhadap Profitabilitas}

Bedasarkan hasil riset, dapat disimpulkan tingkat solvabilitas memperkuat pengaruh FDR terhadap profitabilitas. Hal ini terjadi karena FDR yang lebih tinggi dapat meningkatkan profitabilitas, dan ketika profitabilitas kuat, bank dapat memenuhi kewajibannya. Hasil ini didukung oleh penelitian Minrai (2019) menunjukan hasil tingkat solvabilitas memilki pengaruh positif. Begitu juga pendapatnya Pakpahan (2016) bahwa tingkat solvabilitas memilki pengaruh positif. Namun, hasil ini bertentangan dengan hasil riset oleh Rizki (2019) yang mengatakan bahwa tingkat solvabilitas terhadap profitabilitas berpengaruh negatif. Sesuai dengan hasil riset ini, yaitu semakin rendah DER, semakin baik kinerja perusahaan dan semakin tinggi pengembalian investasi. Sehingga bank perlu meminimalisir dalam melakukan hutang untuk kebutuhan modal, bank dapat melakukan emisi perusahaan di pasar modal agar dapat menarik investor untuk menanamkan dananya. Sehingga bank dapat memperoleh tambahan dana/modal untuk melakukan aktifitas operasional yang lebih menguntungkan karena semakin tinggi keuntungan maka semakin tinggi tingkat profitabilitasnya.

\section{Tingkat Solvabilitas dalam Memoderasi Profit Sharing terhadap Profitabilitas}

Bedasarkan hasil uji t, dapat disimpulkan bahwa tingkat solvabilitas memperkuat pengaruh profit sharingterhadap profitabilitas. Hal ini diakibatkan karena jika bank menawarkan bagi hasil yang tinggi kepada konsumen, maka nasabah akan menaikan jumlah uang yang terkumpul di bank. Sehingga profitabilitas bank juga semakin meningkat. Semakin meningkat profitabilitas tentu berimbas pada kemampuan bank dalam membayar segala kewajibannya. 
Hasil riset ini sejalan dengan Minrai (2019) dan juga pendapatnya Pakpahan (2016) bahwa tingkat solvabilitas memilki pengaruh positif. Semakin besar jumlah pembiayaan yang didistribusikan oleh bank, maka semakin besar pula keuntungan bank tersebut. Namun, hasil ini bertentangan dengan hasil riset oleh Rizki (2019) yang mengatakan bahwa tingkat solvabilitas terhadap profitabilitas berpengaruh negatif.

\section{F. KESIMPULAN}

Berdasarkan analisis yang telah dilakukan, maka dapat disimpulkan bahwa Dana Pihak Ketiga, Financing To Deposit Ratio (FDR), dan Tingkat Solvabilitasmemiliki pengaruh negatif terhadap profitabilitas. Sedangkan Profit Sharing memiliki pengaruh positif terhadap profitabilitas. Adapun Tingkat solvabilitas mampu memperkuat pengaruh Dana Pihak Ketiga, Financing To Deposit Ratio (FDR), dan Profit Sharing terhadap profitabilitas.

\section{REFERENSI}

Afrizal. (2017). Pengaruh Dana Pihak Ketiga, Quick Ratio, Current Asset Dan Non Performance Finance Terhadap Profitabilitas PT Bank Syariah Mandiri Indonesia. Valuta, 3(1), 189-210.

Almunawwaroh, M., \& Marliana, R. (2018). Pengaruh CAR, NPF Dan FDR Terhadap Profitabilitas Bank Syariah Di Indonesia. E-ISSN: 2540-8402 PISSN: 2540-8399. Amwaluna: Jurnal Ekonomi Dan Keuangan Syariah, 2(1), 1-17.

Angraini, D. (2018). Pengaruh Dana Pihak Ketiga, Non Performing Financing, Tingkat Bagi Hasil Dan Modal Sendiri Terhadap Profitabilitas Dengan Pembiayaan Bagi Hasil Sebagai Variabel Intervening Pada Perbankan Syariah. Jurnal Akuntansi Berkelanjutan Indonesia, 1(1), 122-146.

Ariani, K. R., \& Bawono, A. D. B. (2018). Pengaruh Umur Dan Ukuran Perusahaan Terhadap Audit Report Lag Dengan Profitabilitas Dan Solvabilitas Sebagai Variabel Moderating. Riset Akuntansi Dan Keuangan Indonesia, 3(2), 118126.

Asri, N. N. S., \& Suarjaya, A. A. G. (2018). Pengaruh Dana Pihak Ketiga, CAR, Likuiditas, dan Ukuran Perusahaan terhadap Profitabilitas LPD Kabupaten Gianyar. E-Jurnal Manajemen Unud, 7(6), 3384-3411.

Bawono, A., \& Shina, A. F. I. (2018). Ekonometrika Terapan untuk Ekonomi dan Bisnis Islam Aplikasi dengan Eviews. Lembaga Penelitian dan Pengabdian kepada Masyarakat (LP2M) IAIN Salatiga.

Dendawijaya, L. (2009). Manajemen Perbankan. Edisi 2 Jakarta: Ghalia Indonesia. Gunawan, D., Siregar, S., \& Harahap, I. (2019). The Effect Of Car , Nom , ProfitLoss Sharing Financing And Liquidity On Profitability In Islamic 
Commercial Banks And Islamic Business Units In Indonesia. 1, 490-497.

Harun, U. (2016). Pengaruh Ratio-Ratio Keuangan CAR, LDR, NIM, BOPO, NPL Terhadap ROA. Jurnal Riset Bisnis Dan Manajemen, 4(1), 67-82.

Hassoune, A. (2005). Islamic Banks Profitability in an Interest Rate Cycle. International Journal of Islamic Financial Services, 4, 3.

Husaeni, U. A. (2017). Analisis Pengaruh Dana Pihak Ketiga Dan Non Performing Financing Terhadap Return On Asset Pada BPRS Di Indonesia. Jurnal Ekonomi Syariah, 5(October), 1-16.

Indah Ariyanti, Patricia Dhiana P, A. P. (2017). Pengaruh CAR, NPF, NIM, BOPO, Dan DPK Terhadap Profitabilitas Dengan FDR Sebagai Variabel Intervening 2011-2014), (Studi Kasus Perbankan Umum Syariah Tahun. Ekonomi-Akuntansi, 1-15.

Juniarto Koko Mochamad, S. R. F. (2018). Pengaruh NPF, CAR dan FDR Terhadap Profitabilitas Perusahaan Perbankan Syariah. Jurnal Ilmu dan Riset Manajemen. Volume 7, Nomor 6. Edunomika, 02(02), 208-221.

Kasmir. (2010). Pengantar Manajemen Keuangan Lain. Jakarta: Kencana Prenada Media Grup.

Kurniawansyah, D. (2016). Profit Loss Sharing Funding dan Financing Terhadap Profitabilitas Bank Umum Syari' ah di Indonesia dengan Efisiensi dan Risiko Sebagai Mediasi. 18(1), 1-26.

Mahmudah, N., \& Harjanti, R. S. (2016). Analisis Capital Adequacy Ratio, Financing to Deposit Ratio, Non Performing Financing, dan Dana Pihak Ketiga terhadap Tingkat Profitabilitas Bank Umum Syariah Periode 20112013. Seminar Nasional Iptek Terapan, 1(1), 134-143.

Marlinah, A. (2014). Pengaruh Kebijakan Modal Kerja dan Faktor Lainnya terhadap Profitabilitas Perusahaan Manufaktur. Jurnal Bisnis Dan Akuntansi, 16(2).

Medyawati, H., \& Yunanto, M. (2018). The effects ofFDR, BOPO, and profit sharing on the profitability of islamic banks in Indonesia. International Journal of Economics, Commerce and Management, United Kingdom, VI(5), 811-825.

Minrai, S. R. (2019). Pengaruh Rasio Likuiditas Dan Rasio Solvabilitas Terhadap Profitabilitas Perbakan (Studi Empiris Pada Perusahaan Perbankan Yang Terdaftar Di Bursa Efek Indonesia Periode 2015-2017).

Mokoagow, S. W., \& M. F. (2015). Faktor-Faktor yang Memengaruhi Profitabilitas Bank Umum Syariah di Indonesia. Jurnal Manajemen Bisnis Dan Kewirausahaan, Vol. 6 No.3

Munir, M. (2018). Analisis Pengaruh CAR, NPF, FDR dan Inflasi terhadap Profitabilitas Perbankan Syariah di Indonesia. Ihtifaz: Journal of Islamic Economics, Finance, and Banking, 1(1), 89.

Pakpahan, E. E. (2016). Pengaruh Solvabilitas Terhadap Profitabilitas Di Nathan's Famous Inc. Jurnal Administrasi Bisnis, Volume 5, 105-111.

Risalah, S., Anshori, M. Y., \& Primasari, N. S. (2018). The Impact of CAR, BOPO, NPF , FDR, DPK and Profit Sharing on ROA of Sharia Banks Listed in Bank Indonesia (Study at Sharia Commercial Banks). International Conference on Technopreneurship and Education, 240-245.

Rizki, M. S. (2019). Pengaruh Rasio Likuiditas dan Solvabilitas Terhadap Profitabilitas dengan Pendekatan Structural Equation Modelling. BENEFIT 
Jurnal Manajemen Dan Bisnis, 4(1), 94-101.

Sihombing, N. H., \& Yahya, M. R. (2016). Pengaruh Kebijakan Spin-Off, Beban Operasional Pendapatan Operasional (BOPO), Dana Pihak Ketiga (DPK), dan Non Performing Financing (NPF) Terhadap Profitabilitas Perbankan Syariah di Indonesia. Jurnal Ilmiah Mahasiswa Ekonomi Akuntansi, 1(2), 127-137.

Simatupang, A., \& Franzlay, D. (2016). Capital Adequacy Ratio(CAR), Non Performing Financing (NPF), Efisiensi Operasional (BOPO) dan Financing to Deposit Ratio (FDR) Terhadap Profitabilitas Bank Umum Syariah di Indonesia. Jurnal Administrasi Kantor, 4(2), 466-485.

Yudiana, Fetria Eka. (2014). Manajemen Pembiayaan Bank Syariah. Salatiga: STAIN Salatiga Press. 